\title{
Changes in the structural components of the spleen in experimental obesity and its correction
}

\author{
T. V. Harapko \\ Uzhhorod National University, Medical Faculty, Department of Human Anatomy and Histology, Uzhhorod \\ Corresponding author. E-mail: garapkotv@gmail.com
}

Paper received 04.09.19; Accepted for publication 20.09.19.

\section{https://doi.org/10.31174/SEND-NT2019-206VII25-06}

\begin{abstract}
The paper presents and analyzes data from an experimental study conducted on white rats of reproductive age. The aim of the study was to study the morphometric and histological changes of the rat spleen parenchyma in experimental obesity and its correction with melatonin. Eight weeks later, a significant decrease in the relative area of white pulp in the spleen parenchyma of white rats of males and females was observed, and an increase in the relative area of red pulp was observed. After two weeks of HCD, after which six weeks of HCD + melatonin the relative area of white and red pulp almost corresponds to the indicators of intact animals.
\end{abstract}

Keywords: obesity, spleen, white pulp, red pulp, melatonin.

Introduction. Overweight in the modern world is a common phenomenon. An increasing percentage of people suffer from obesity and this figure is steadily increasing. However, most perceive the problem as aesthetic. Excess body weight and obesity is a recognized risk factor for the development of metabolic diseases, including insulin resistance, type 2 diabetes, hypertension, non-alcoholic fatty liver disease (NAFLD), polycystic ovarian disease and some cancers [2, 3, 5-8].

Analysis of recent research. It is revealed that with increase of the patient's body mass index (BMI) the systolic blood pressure, diastolic blood pressure, heart rate, the absolute value of the thickness of the left ventricular wall, and the relative thickness of the walls increase[1]. The effect of obesity on the structure of the kidneys in patients with hypothyroidism is analyzed. A decrease in the glomerular filtration rate was detected [4].

Since the fact that obesity causes changes in the structure of organs, has already been described and proven by many, the possibility of correcting them remains an urgent question.

The aim of the study. To study morphometric and histological changes of the rat spleen parenchyma in experimental obesity and its correction with melatonin.

Materials and methods. We carried out the study on 66 white rats of reproductive age (2.5-6.5 months) weighing 120-280 g.

Microanatomy of the spleen structural components in white rats under conditions of physiological norm was studied on 10 intact animals. Experimental animals were divided into 4 groups: the first group (10 animals), being fed a high-calorie diet (HCD) for eight weeks; the second group (10 animals), being fed a high-calorie diet (HCD) for two weeks, whereupon by a two weeks fed a HCD with melatonin; the third group (10 animals), being fed a highcalorie diet for two weeks, whereupon by a four weeks fed a HCD with melatonin; the fourth group (10 animals), being fed a high-calorie diet for two weeks, whereupon by a six weeks fed a HCD with melatonin. Each group included 5 male and 5 female rats. High-calorie diet was achieved due to the fact that glutamate sodium was added into food in a dose of $0.07 \mathrm{~g} / \mathrm{kg}$ of rat body weight, and fructose solution was added into water. The dose of melatonin was $10 \mathrm{mg} / \mathrm{kg}$ rat body weight, administered orally daily in the afternoon at the same time.
Control was provided by 16 white rats, fed a standard diet of vivarium instead of a high-calorie diet.

All experimental animals were kept under the vivarium of the Danylo Halytskyi Lviv National Medical University. The study was performed in accordance with the provisions of the European Convention for the protection of vertebrate animals used for experimental and other scientific purposes (Strasbourg, 1986), Council of Europe Directives 86/609 / EEC (1986), Law of Ukraine No. 3447-IV “On the Protection of Animals from Cruelty", the general ethical principles of experiments on animals adopted by the First National Congress of Ukraine on Bioethics (2001).

Morphometric studies were performed using a system of visual analysis of histological preparations. Images from the histological preparations of the spleen in the computer monitor were displayed from the MICROmed SEO SCAN microscope by means of the Vision CCD Camera.

Morphometric studies were performed using VideoTest5.0, CAAPA Image Base, Stepanizer, and Microsoft Exel on a personal computer. The studies were performed at certain times of the experiment in drugs stained with hematoxylin and eosin.

Results and its discussion. The spleen is a secondary immune organ in which antigen-dependent proliferation and differentiation of $\mathrm{T}$ and $\mathrm{B}$ lymphocytes occurs. The histological structure of the spleen of intact animals corresponds to the species norm. The fibrous membrane surrounds the spleen from the outside, from which the spleen lining trabecules inside the organ. The parenchyma is formed by white and red pulp (Fig. 1). The white pulp consists of periarteriolar lymphoid sheats and splenic lymphatic follicles. The red pulp is represented by clusters of blood cells that are surrounded by reticular cells.

Eight weeks after HCD, there is a significant decrease in the relative area of white pulp in the spleen parenchyma of white rats of males and females to $21.6 \pm 1.22 \%$ and 21.78 $\pm 1.3 \%$, which is $16.2 \%$ and $17.4 \%$ less parameters of intact group of animals (Table. 1). Accordingly, the relative area of the red pulp increases to $78.4 \pm 1.45 \%$ in male rats and to $78.22 \pm 1.54 \%$ in female rats. These parameters are $5.6 \%$ and $6.2 \%$ higher than the parameters of the intact group of animals (Table 1). 


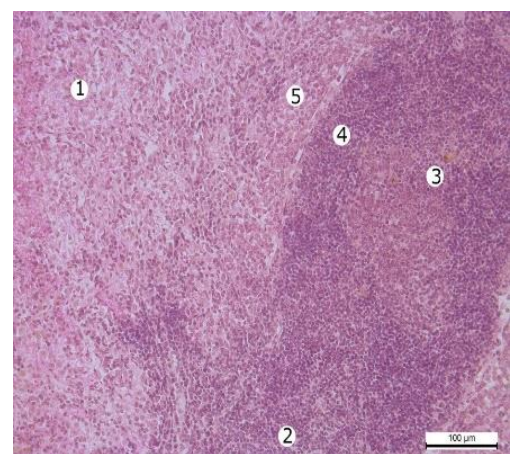

Fig. 1. Fragment of the spleen of an intact white rat male. Stained with hematoxylin and eosin. Magnif.: A. obj. $\times 20$, ocul. $\times 10$. Designations: 1 - red pulp; 2 - white pulp; 3 - germinal center of lymphatic follicle; 4 - mantle zone; 5 - marginal zone.
After eight weeks of high-calorie diets, the number of monocytes, macrophages and plasmocytes in both male and female rats increased. Hemosiderin residues occur both in the cytoplasm of macrophages and in intercellular spaces (Fig. 2). The presence of iron-containing pigment is evidence of erythrocyte death. The proportion of reticular connective tissue in the splenic strands increases. The veins of the red pulp are full-blooded. There is an immunoinducing effect with enhanced proliferation of activated lymphocytes and their subsequent differentiation into plasma cells. Around small vessels, eosinophilic aggregation and lipid accumulation in the enlarged sinuses are found.

Table 1. Indices of the relative area of white and red pulp levels in white rats, $\%(M \pm m)$

\begin{tabular}{|l|c|c|c|c|}
\hline \multirow{2}{*}{\multicolumn{1}{|c|}{ Group name }} & \multicolumn{2}{|c|}{ White male rat } & \multicolumn{2}{c|}{ White female rat } \\
\cline { 2 - 5 } & $\mathrm{S}_{\text {white pulp }} \%$ & $\mathrm{~S}_{\text {red pulp } \%}$ & $\mathrm{~S}_{\text {white pulp, } \%}$ & $\mathrm{~S}_{\text {red pulp }} \%$ \\
\hline Intact animals & $25.78 \pm 1.18$ & $74.22 \pm 1.33$ & $26.38 \pm 1.02$ & $73.62 \pm 1.4$ \\
\hline Group I - 8 weeks fed a HCD & $21.6 \pm 1.22$ & $78.4 \pm 1.45$ & $21,78 \pm 1.3$ & $78.22 \pm 1.54$ \\
\hline Group II - 2 weeks fed a HCD, 2 weeks HCD+melatonin & $27.69 \pm 1.39$ & $72.31 \pm 1.62$ & $27.72 \pm 1.49$ & $72.28 \pm 1.74$ \\
\hline Group III - 2 weeks fed a HCD, 4 weeks HCD+melatonin & $26.7 \pm 1.22$ & $73.3 \pm 1.78$ & $27.26 \pm 1.08$ & $72.74 \pm 1.48$ \\
\hline Group IV - 2 weeks fed a HCD, 6 weeks HCD+melatonin & $25.34 \pm 1.09$ & $74.66 \pm 1.69$ & $26.35 \pm 1.19$ & $73.65 \pm 1.58$ \\
\hline
\end{tabular}

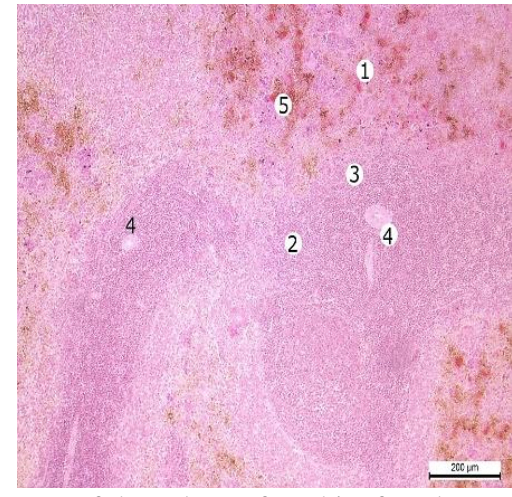

Fig. 2. Fragment of the spleen of a white female rat after 8 weeks fed a HCD. Stained with hematoxylin and eosin. Magnif.: A. obj $\times 10$, ocul. $\times 10$. Designations: $1-$ red pulp; 2 - white pulp, lymphatic follicle; 3 - fuzzy differentiation of lymphatic follicle regions; 4 - central artery; 5 - accumulation of hemosiderin and lipids in the venous sinuses of the red pulp.

Morphometric indices in the second group of animals (two weeks of HCD, followed by two weeks of HCD + melatonin) indicate that the relative area of white pulp in the spleen parenchyma of white rats of males and females increased by $7.4 \%$ and $5.1 \%$, respectively, compared to the intact group of animals, and is $27.69 \pm 1.39 \%$ and $27.72 \pm$ $1.49 \%$ (Table 1). Accordingly, the relative area of the red pulp decreases to $72.31 \pm 1.62 \%$ in male rats and $72.28 \pm$ $1.74 \%$ in female rats. These figures are $2.6 \%$ and $1.8 \%$ less than the parameters of the intact group of animals (Table $1)$.

Histological preparations have a moderate amount of iron-containing pigment in the red pulp of the spleen, some arteries with a thickened wall, their lumen tightly filled with elements of blood. Many lymphatic follicles contain a germinal center.

Morphometric indices in the third group of animals (two weeks of HCD, followed by four weeks of HCD + melatonin) indicate that the relative area of white pulp in the spleen parenchyma of white rats in males and females decreased by $3.6 \%$ and $1.7 \%$, respectively. group of animals and is $26.7 \pm 1.22 \%$ and $27.26 \pm 1.08 \%$. These indicators are $3.57 \%$ and $3.3 \%$ more than the parameters of the intact group of animals (Table 1). Accordingly, the relative area of the red pulp is increased by 1.4 and $0.6 \%$ compared to the previous group of animals and is $73.3 \pm 1.78 \%$ in male rats and $72.74 \pm 1.48 \%$ in female rats. These figures are $1.2 \%$ less than the parameters of the intact group of animals (Table 1).

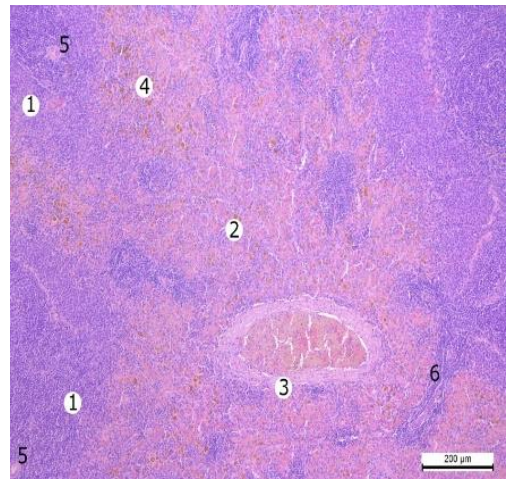

Fig. 3. Fragment of the spleen of a white female rat after 2 weeks fed a HCD, after what 2 weeks HCD+melatonin. Stained with hematoxylin and eosin. Magnif.: A. obj. $\times 10$, ocul. $\times 10$. Designations: 1 -white pulp; 2 - red pulp; 3 - full-blooded artery with thikness wall; $4-$ accumulation of hemosiderin in the red pulp; 5 - central artery; 6 - periarteriolar lymphoid sheats.

Morphometric indices in the fourth group of animals (two weeks of HCD, followed by six weeks of HCD + melatonin) indicate that the relative area of white pulp in the spleen parenchyma of white rats of males and females decreased by 5.1 and $3.3 \%$, respectively. with the previous group of animals and is $25.34 \pm 1.09 \%$ and $26.35 \pm 1.19 \%$. These figures are $1.7 \%$ and $0.1 \%$ less than the parameters of the intact group of animals (Table 1). Accordingly, the relative area of the red pulp increases by $1.9 \%$ and $1.3 \%$ compared to the previous group of animals and is $74.66 \pm$ $1.69 \%$ in male rats and $73.65 \pm 1.58 \%$ in female rats . 
These figures by $0.6 \%$ and $0.04 \%$ exceed the parameters of the intact group of animals (Table 1).

The number of lymphatic follicles containing the germinal centers decreases, the boundaries between the follicles are clear, the differentiation into zones is followed almost everywhere (Fig. 4). Some veins are enlarged, full-blooded. The amount of hemosiderin in the parenchyma of the spleen is moderate.

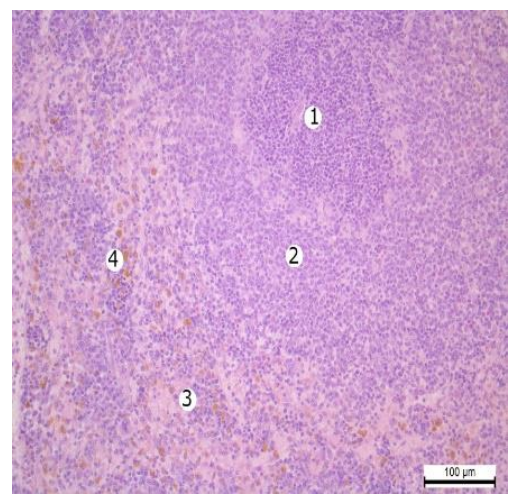

Fig. 4. Fragment of the spleen of a white female rat after 2 weeks fed a HCD, after what 6 weeks HCD+melatonin. Stained with hematoxylin and eosin. Magnif.: A. obj. $\times 20$, ocul. $\times 10$.
Designations: 1 - white pulp, lymphatic follicle; 2 - marginal zone; 3 - red pulp; 4 - hemosiderin in the red pulp.

Conclusions. As a result of a study in rats males and females, we found:

1. After eight weeks of HCD, a significant decrease in the relative area of white pulp in the spleen parenchyma of white rats of males and females was observed by $16.2 \%$ and $17.4 \%$, respectively, and a corresponding increase in the relative area of red pulp by $5.6 \%$ and $6.2 \%$.

2. After two weeks of HCD, after which six weeks of $\mathrm{HCD}+$ melatonin the relative area of white pulp in the spleen parenchyma of white rats in males and females was $1.7 \%$ and $0.1 \%$ less than the parameters of the intact group. Accordingly, the relative area of the red pulp by $0.6 \%$ and $0.04 \%$ exceeds the parameters of the intact group of animals.

3. Under the conditions of melatonin correction, it is found that the boundaries between the follicles are clear, differentiation into zones is followed almost everywhere, some veins are enlarged, full-blooded, the amount of hemosiderin in the parenchyma of the spleen is moderate.

\section{LITERATURE}

1. Кожем’яка Г.В., Ковальова О.М., Ащеулова Т.В., Гончарь О.В. Вплив ожиріння на формування змін геометрії міокарда у хворих на гіпертонічну хворобу // Проблеми безперервної медичної освіти та науки, 2016. Вип. 4. С. 29 34.

2. Костіцька I.O. Патогенетична роль адипоцитокінів у розвитку неалкогольної жирової хвороби печінки (огляд літератури) // Укр. мед. часопис, 2010. Вип. 4 (78). С. 84-90.

3. Шварц В. Жировая ткань как эндокринный орган // Проблемы эндокринологии, 2009. Вып. 1. С. 38-44.

4. Wang, Y., Chen, X., Song, Y., Caballero, B., Cheskin, L.J. Association between obesity and kidney disease: a systemic review and meta-analysis // Kidney Int, 2008. Is. 73. P. 19-33.
5. Barness, L.A., Opitz, J.M., Gilbert-Barness, E. Obesity: genetic, molecular, and environmental aspects // Am. J. Med. Genet, 2007. Is. 143 (24). P. 3016-3034. doi:10.1002/ajmg.a.32035.

6. Hall, J.E.. The kidney, hypertension and obesity // Hypertension, 2003. Is. 41 (3). P. 625-633.

7. Kothari, V., Luo, Y., Tornabene, T., O’Neill, A.M., Greene, M.W., Geetha, T., et al. High fat diet induces brain insulin resistance and cognitive impairment in mice // Biochim Biophys Acta, 2017. Is. 1863 P. 499-508.

8. Wang, H.J., Si, Q.J., Shan, Z.L., Guo, Y.T., Lin, K., Zhao, X.N., et al. Effects of body mass index on risks for ischemic stroke, thromboembolism, and mortality in Chinese atrial fibrillation patients: a single-center experience // PLoS One, 2015. Is. 10 (4). P. 231-242.

\section{REFERENCES}

1. Kozhem'yaka, G.V., Koval'ova, O.M., Ashheulova, T.V., Gonchar', O.V. The effect of obesity on the formation of changes in the geometry of the myocardium in patients with hypertension // Problemy` bezperervnoyi medy 'chnoyi osvity` ta nauky`, 2016. Vy`p. 4. C. 29-34.
2. Kosticz ka, I.O. Pathogenetic role of adipocytokines in the development of non-alcoholic fatty liver disease (literature review) // Ukr. med. chasopy`s, 2010. Vy`p. 4 (78). C. 84-90.

3. Shvarts, V. Adipose tissue as an endocrine organ // Problemyi endokrinologii, 2009. Vyip. 1. S. 38-44. 